\title{
The Effect of Microbes and Fly Ash to Improve Concrete Performance
}

\author{
Adlizie Rifkianda Muhammad ${ }^{1}$, Januarti Jaya Ekaputri ${ }^{1 *}$, and Makno Basoeki ${ }^{2}$ \\ ${ }^{1}$ Civil Engineering Department, FTSPK, ITS, Kampus ITS Sukolilo, Surabaya 60111, Indonesia \\ ${ }^{2}$ Bioconc Center Foundation, Sidoarjo, Indonesia \\ * Corresponding author: januarti@ce.its.ac.id
}

(Received: September $18^{\text {th }} 2021$; Revised: October $19^{\text {th }} 2021$; Accepted: October $20^{\text {th }} 2021$ )

\begin{abstract}
This paper presents the application of fly ash combining with microbes in concrete to reduce cement content. A class F fly ash as cement replacementwas applied with ratios of $20 \%, 30 \%, 40 \%$, and $50 \%$ to reduce hydration heat. Microbes from bacterial consortium were applied to as the filler to increase concrete compressive strength. The concrete mix design from SNI 03-2834-2000 was applied for a compressive strength target of $30 \mathrm{MPa}$. The mechanical test was carried out consisting compressive and tensile test. Concrete workability and the heat hydration measurement were performed for fresh concrete. The results showed that the maximum strength of $45.10 \mathrm{MPa}$ was obtained from specimens with $30 \%$ fly ash content. Application of microbes associated with fly ash content of $40 \%$ showed the maximum strength of 48.47 MPa. It was found that the tensile strength also increased with the application of fly ash and microbes. Hydration temperature of concrete decreased with the increase of the ash content. This proves that the application of fly ash and microbes in concrete can reduce the cement as well as increasing the concrete performance.
\end{abstract}

Keywords: Fly Ash; Concrete Compressive Strength; Microbes; Workability; Hydration Heat.

\section{Introduction}

Concrete is a material commonly used in building structures, roads, and bridges. It has sufficient strength to support the weight of a structure. Normal concrete is concrete that weighs up to 2200 $-2500 \mathrm{~kg} / \mathrm{m}^{3}$ [1].

Infrastructures development in Indonesia using concrete is increasing rapidly. However, in concrete mix, cement is utilized greatly requiring high energy. It is also known that cement is a significant contributor to air pollution such as dust particles as well as $\mathrm{CO}_{2}$ emissions. This makes cement become one of the factors causing global warming. To overcome this problem, concrete technology experts proposed cement replacement to materials increase strength, durability, more economical, and environmentally friendly. One of these efforts is replacing cement with fly ash and microbes application.

There are some results of fly ash replacement in concrete. The replacement of cement with fly ash can be used at $10 \%$ fly ash content of cement weight $\left(657 \mathrm{~kg} / \mathrm{m}^{3}\right.$ of concrete) and the compressive strength increased as the fly ash content increased to $20 \%, 30 \%$, and $40 \%$. An optimal 28-day compressive strength of $122 \mathrm{MPa}$ was achieved when $40 \%$ fly ash was applied [2]. Ready-mix concrete mixturs which cement was replaced with fly ash of $30-33 \%$ showed the same compressive strength results with normal concrete [3]. 
In Indonesia, there have been many studies on tensile strength of concrete containing fly ash. One of them was conducted by Marthinus, Sumajouw, and Windah [4]. They replaced cement weight (450 kg/m $\mathrm{m}^{3}$ of concrete) with fly ash of $30 \% ; 40 \% ; 50 \% ; 60 \%$; and $70 \%$. The maximum tensile strength of $3.21 \mathrm{MPa}$ was achieved by $30 \%$ fly ash at 28 days. The lowest tensile strength of 0.82 $\mathrm{MPa}$ at 7 days, was given by specimens with $70 \%$ fly ash.

The effect of fly ash as cement replacement is to reduce the hydration heat. A study revealed that the exposure temperature at $150 ; 250 ; 350 ; 450 ; 500^{\circ} \mathrm{C}$ in fly ash concrete, resulted in reducing of corresponding temperature in the fly ash concrete in 85 minutes to $111 ; 172 ; 192 ; 248$; and $321^{\circ} \mathrm{C}$, respectively [5].

On the other hand, a concept of bio-cementing has been discovered as a new material in concrete called bio-concrete. Bacillus megaterium $\left(30 \times 10^{5} \mathrm{cfu} / \mathrm{ml}\right)$ mixed in fresh concrete increased the compressive strength of concrete up to $24 \%$ from $50 \mathrm{MPa}$ to $64 \mathrm{MPa}$ owing to deposition of $\mathrm{CaCO}_{3}[6]$. The compressive strength, split tensile strength and flexural strength of concrete were improved by using fly ash (10\% by weight of cement) enriched by Bacillus sphaericus. The results were compared with control specimens, for compressive strength of $29.33 \mathrm{MPa}$ to 32.50 $\mathrm{MPa}$, split tensile strength from 3.2 MPa to $4.14 \mathrm{MPa}$, and flexural strength from $3.33 \mathrm{MPa}$ to 3.5 MPa [7]. The use of fly ash enriched with Bacillus sphaericus can replace cement in concrete because economically, reduce $\mathrm{CO}_{2}$ emissions and save electricity consumption in cement production. That states microbes can improve the quality of concrete, but microbes grow weaker against high temperatures. The growth of bacteria (ammonia-oxidizing bacteria) was very hampered by high temperatures, especially at temperatures over $40^{\circ} \mathrm{C}[8]$.

There is a link between fly ash and microbes in the concrete mixture to contribute in sustainable green infrastructures. The influence of microbes to the fresh concrete as well as the concrete performance as a benchmark of fly ash application in normal concrete is the main discussion in this study.

\section{The mechanism of fly ash and microbes in concrete}

When the hydration reaction of the cement occurred, the $\mathrm{C}_{3} \mathrm{~S}$ minerals from cement reacts with water $\left(\mathrm{H}_{2} \mathrm{O}\right)$ to produce calcium silicate hydrate $(\mathrm{CSH})$ and $\mathrm{Ca}(\mathrm{OH})_{2}$ as expressed in Eq. (1).

$$
\mathrm{C}_{3} \mathrm{~S}+\mathrm{H}_{2} \mathrm{O} \rightarrow \mathrm{CSH}+\mathrm{Ca}(\mathrm{OH})_{2}
$$

The result of the cement hydration reaction is $\mathrm{CSH}$ which is the adhesive material from the cement that build the concrete strength, while $\mathrm{Ca}(\mathrm{OH})_{2}$ is a solution that fills pores in concrete. When fly ash with $\mathrm{Ca}(\mathrm{OH})_{2}$ starts a pozzolanic reaction, it produces aditional CSH that fills the concrete pores. It is presented in (Eq. (2)).

$$
\mathrm{Ca}(\mathrm{OH})_{2}+\mathrm{SiO}_{2}+n \mathrm{H}_{2} \mathrm{O} \rightarrow \mathrm{CaOSiO}(n+1) \mathrm{H}_{2} \mathrm{O}=\mathrm{CSH} \text { (new) }
$$

The mechanism of microbes increases the compressive strength of concrete. Microbes and water reacts in concrete, then produces ammonia and $\mathrm{CO}_{2}$. Ammonia and $\mathrm{CO}_{2}$ in the concrete pores react with calcium oxide $\left(\mathrm{Ca}(\mathrm{OH})_{2}\right)$ and produced calcium carbonate $\left(\mathrm{CaCO}_{3}\right)$ which settles in the concrete pores. These mechanisms are expressed in Eq. (3) and Eq. (4).

$$
\begin{gathered}
\left(\mathrm{NH}_{2}\right)_{2} \mathrm{CO}+\mathrm{H}_{2} \mathrm{O} \rightarrow \mathrm{CO}_{2}+2 \mathrm{NH}_{3} \text { (ammonia) } \\
\mathrm{CO}_{2}+2 \mathrm{NH}_{3}+\mathrm{Ca}(\mathrm{OH})_{2} \rightarrow \mathrm{CaCO}_{3}+2 \mathrm{NH}_{3}+\mathrm{H}_{2} \mathrm{O}
\end{gathered}
$$

The two chemical reactions in Eq. (2) and Eq. (4) both reduced $\mathrm{Ca}(\mathrm{OH})_{2}$ which is a solution located in concrete pores so that concrete pores were closed by calcium silicate hydrate (CSH) and calcite $\left(\mathrm{CaCO}_{3}\right)$. This causes a denser concrete. 


\section{Materials and Work Methods}

\subsection{Materials}

\subsubsection{Cement and Fly Ash}

The cement used was Portland cement composite with a specific gravity of $2.98 \mathrm{gr} / \mathrm{cm}^{3}$. A class F Fly ash was selected from PT. Petrokimia Gresik, Indonesia with a specific gravity of 2.37 $\mathrm{gr} / \mathrm{cm}^{3}$. Its chemical contents are listed in Table 1.

Table 1. Chemical content of fly ash

\begin{tabular}{ccccccccccc}
\hline Oxides & $\mathrm{SiO}_{2}$ & $\mathrm{Al}_{2} \mathrm{O}_{3}$ & $\mathrm{CaO}$ & $\mathrm{Fe}_{2} \mathrm{O}_{3}$ & $\mathrm{~K}_{2} \mathrm{O}$ & $\mathrm{MgO}$ & $\mathrm{Na}_{2} \mathrm{O}$ & $\mathrm{SO}_{3}$ & $\mathrm{TiO}_{2}$ & LOI \\
\hline (\% by mass) & 46.61 & 23.31 & 6.77 & 14.45 & 1.27 & 1.70 & 0.54 & 1.55 & 0.79 & 3.80 \\
\hline
\end{tabular}

\subsubsection{Coarse aggregate and fine aggregate}

Coarse aggregate was selected having maximum size of $20 \mathrm{~mm}$ with a specific gravity of 2.69 $\mathrm{gr} / \mathrm{cm}^{3}$. River sand was selected for the fine aggregate with a specific gravity of $2.59 \mathrm{gr} / \mathrm{cm}^{3}$.

\subsubsection{Superplasticizer}

The superplasticizer used was Tancem $60 \mathrm{RP}$, as a substitute for water by reason of lower w/c in some mixtures. This superplasticizer includes admixture type F (high range water reducer) [9]. The recommended dose is $0.2 \%$ by binder mass.

\subsubsection{Microbes}

The microbial used was a bacterial consortium from Bioconc Foundation Center, Indonesia. Bioconc is a biotechnology product in the form of a liquid made from organic/natural ingredients, denatured proteins, polymers surfactants, and organic minerals that have been fermented by beneficial microbes [10]. It is not pathogenic and has a $\mathrm{pH}$ of 8.8. The dose used was $400 \mathrm{ml} / \mathrm{m}^{3}$ of concrete [11].

\subsection{Work Methods}

\subsubsection{Mix Design}

Indonesia standard for miz design was used for the compressive strength target at 28-days of 30 $\mathrm{MPa}$. The water/binder ratio was limited at a minimum of 0.3 to guarantee the convenience of using fly ash in the job mix, and the mix design of 10 variations is listed in Table 2.

Table 2. Mix design of fly ash and microbial concrete per $\mathrm{m}^{3}$ of concrete

\begin{tabular}{ccccccccccc}
\hline No & Code & $\begin{array}{c}\text { Fly } \\
\text { Ash } \\
(\%)\end{array}$ & $\begin{array}{c}\text { Cement } \\
(\mathrm{kg})\end{array}$ & $\begin{array}{c}\text { Fly } \\
\text { Ash } \\
(\mathrm{kg})\end{array}$ & $\begin{array}{c}\text { Water } \\
(\mathrm{kg})\end{array}$ & $\begin{array}{c}\text { Fine } \\
\text { Agg. } \\
(\mathrm{kg})\end{array}$ & $\begin{array}{c}\text { Coarse } \\
\text { Agg. } \\
(\mathrm{kg})\end{array}$ & $\begin{array}{c}\text { Microbes } \\
(0,4 \mathrm{~L})\end{array}$ & $\begin{array}{c}\text { HRWR } \\
(\mathrm{kg})\end{array}$ & W/B \\
\hline 1 & 0FA & 0 & 387 & 0 & 205 & 943 & 871 & 0 & 0 & 0.53 \\
2 & 20FA & 20 & 367 & 92 & 167 & 859 & 935 & 0 & 0.92 & 0.42 \\
3 & $30 \mathrm{FA}$ & 30 & 389 & 167 & 163 & 794 & 913 & 0 & 1.11 & 0.37 \\
4 & 40FA & 40 & 415 & 277 & 158 & 734 & 844 & 0 & 1.38 & 0.32 \\
5 & $50 \mathrm{FA}$ & 50 & 395 & 395 & 154 & 695 & 799 & 0 & 1.58 & 0.3 \\
6 & 0FAM & 0 & 387 & 0 & 205 & 943 & 871 & 0.4 & 0 & 0.53 \\
7 & 20FAM & 20 & 367 & 92 & 167 & 859 & 935 & 0.4 & 0.92 & 0.42 \\
8 & 30FAM & 30 & 389 & 167 & 163 & 794 & 913 & 0.4 & 1.11 & 0.37 \\
9 & 40FAM & 40 & 415 & 277 & 158 & 734 & 844 & 0.4 & 1.38 & 0.32 \\
10 & $50 \mathrm{FAM}$ & 50 & 395 & 395 & 154 & 695 & 799 & 0.4 & 1.58 & 0.3 \\
\hline
\end{tabular}

Note: $\quad$ xxFA = Percentage Fly Ash in Concrete; FAM=Concrete containing microbes. 


\subsubsection{Curing process}

Specimens were cured at moist condition with covering the concrete with wet sacks or cloth. Moist curing was stopped 24 hours before mechanical testing conducted. It is well known that the strength of HVFA (high volume fly ash) concrete increased as well as decreasing of water permeability of concrete [12].

\subsubsection{Manufacture and test of the specimen}

The specimen was made in cylindrical molds with a diameter of $10 \mathrm{~cm}$ with a height of $20 \mathrm{~cm}$ and a cube mold $(15 \times 15 \times 15 \mathrm{~cm})$. The tests were divided into mechanical testing and fresh concrete testing. The mechanical tests were compressive strength and a split tensile strength test. Workability test and hydration heat monitoring were conducted for the fresh concrete.

\section{Analysis and Discussion}

\subsection{Concrete compressive strength}

The results of compressive strength at 28 days with variations of fly ash are presented in Fig. 1. The specimens with bacteria is illustrated in a red mark.

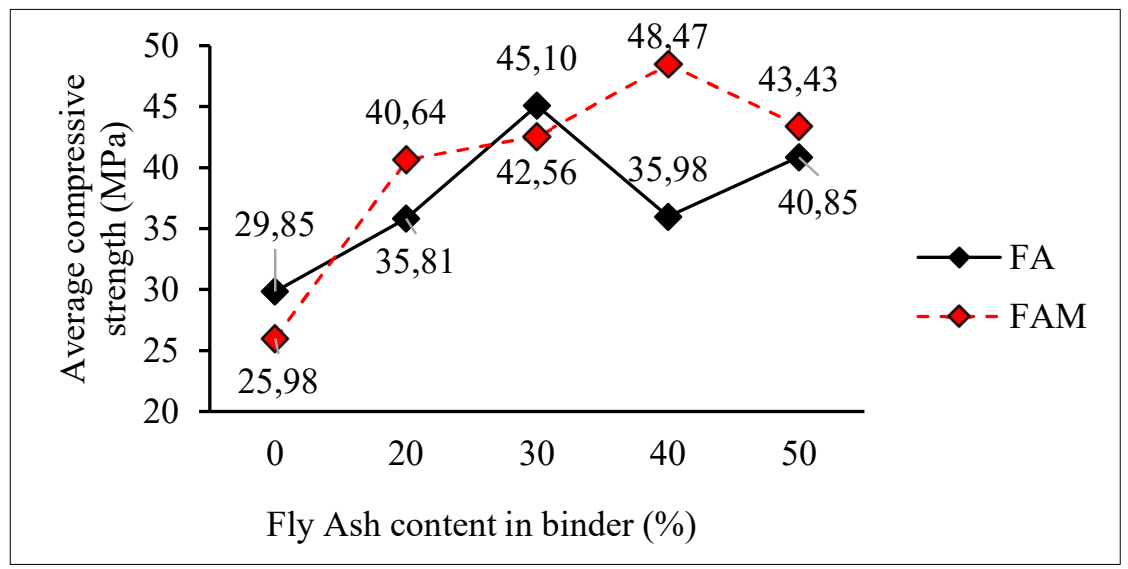

Fig. 1. The 28-day compressive strength with variations of fly ash

In Fig. 1, the use of fly ash in concrete increases the compressive strength and optimum variation of fly ash by $30 \%$. Concrete strength at 28 days with $30 \%$ fly ash content (30FA) increased by $51 \%$ from control specimen (0FA). A study reported that replacement of cement with fly ash is $30 \%$ increased compressive strength by $15.6 \%$ [13]. Concrete strength at 28 days of age with $40 \%$ fly ash containing microbes (40FAM) increased by $62 \%$ from the control. Another study showed that concrete containing $10 \%$ fly ash with Sporosarcina pasteurii increased its strength of $20 \%$ as compared to the normal specimen [14]. In Fig. 1., the influence of microbes increases the ash content up to $40 \%$, but in the $50 \%$ fly ash content, the influence of microbes was reduced, due to limited cement amount so that the availability of $\mathrm{Ca}(\mathrm{OH})_{2}$ or portlandite reacted with fly ash and microbes. However, the influence of microbes on concrete without fly ash reduced the strength. The 28 -day strength of specimen 0FAM decreased by $13 \%$ as compared to specimen $0 \mathrm{FA}$. The decrease was likely caused by the weaken of microbes at high temperature during early hydration in the concrete. It is known that bacteria from Sporosarcina pasteurii produced urease enzyme was optimal in concrete at $25^{\circ} \mathrm{C}$ [15]. Bacterial growth (ammonia-oxidizing bacteria) was inhibited by high temperatures, especially at temperatures more than $40^{\circ} \mathrm{C}$ [8]. It is concluded that when the hydration temperature approaches $25^{\circ} \mathrm{C}$, the urease enzyme 
production becomes more optimum and if it exceeds $40^{\circ} \mathrm{C}$, the urease enzyme production becomes hindered. Another report on the addition of Bacillus megaterium to concrete without fly ash increased the compressive strength of concrete up to $16.1 \%$ of the normal compressive strength of $33 \mathrm{MPa}$ [16].

In Fig. 2., there is a significant increase in the compressive strength of concrete from the age of 3 days to 14 days. In general, steady strength started from the age of 21 days to the concrete age of 28 days showed by concrete without bacteria and fly ash. However, a tendency of strength increase after 28 days showed by bacterial specimens. It is in accordance with a study on fly ash concrete that the strength increased at the later age [17]. Pozzolanic reaction incorporating with the bio-cementation in concrete pores resulted in denser concrete at the later age. This mechanism is optimized at the bacterial specimens containing $30 \%$ fly ash.

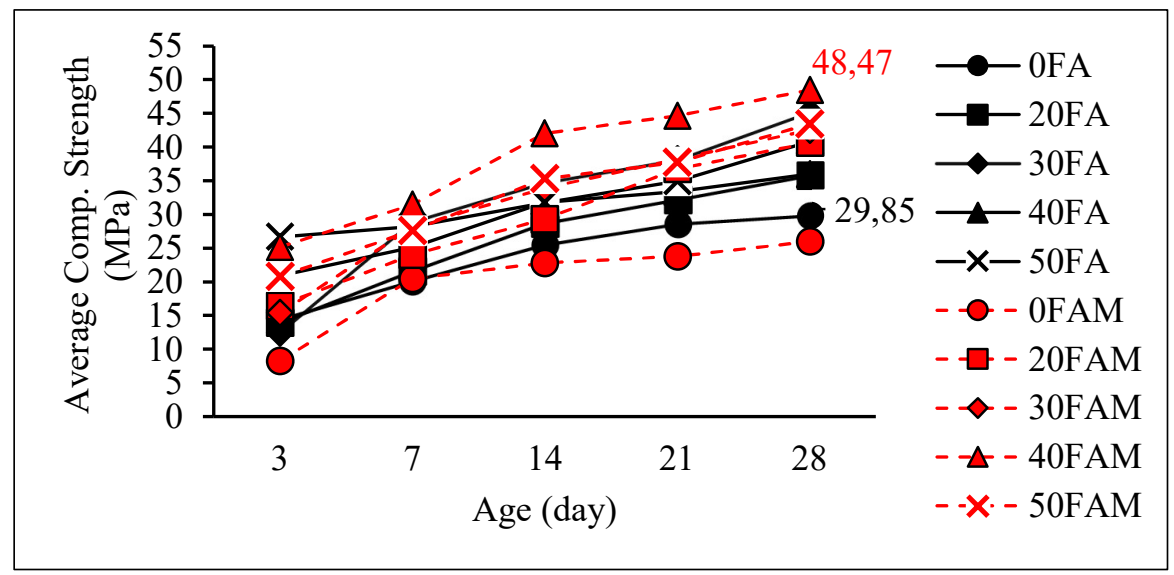

Fig. 2. Compressive strength of concrete with the variation of fly ash content

\subsection{Concrete splitting tensile strength}

The graph of the relationship of tensile strength to fly ash content is provided in Fig. 3. The red mark represents specimens containing microbes.

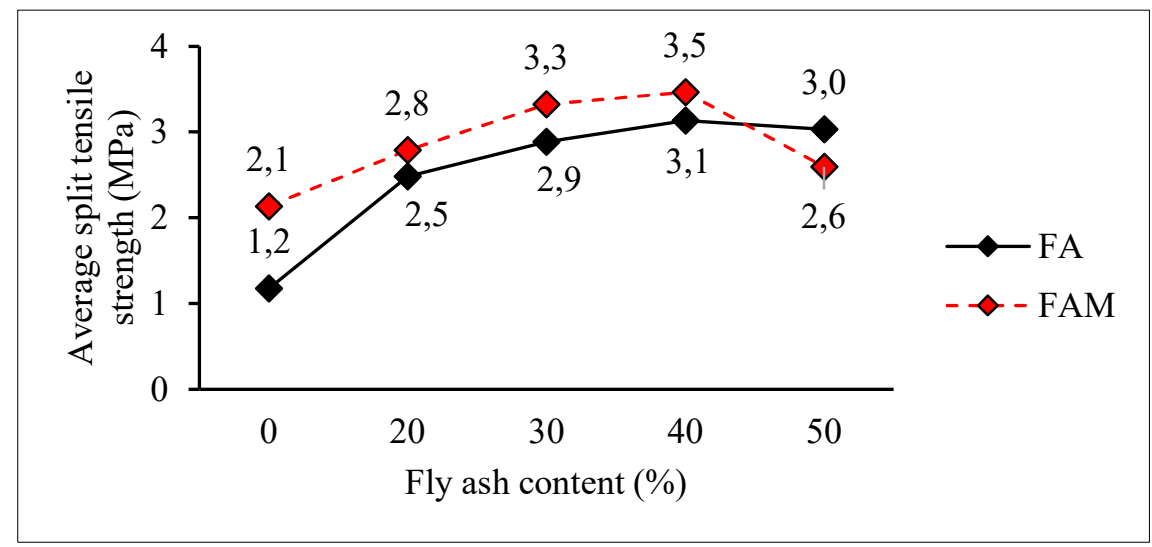

Fig. 3. Effect of fly ash content on the tensile strength

In general, all split tensile strength increases with the increasing of ash content. The maximum split tensile strength is shown by specimen 40FAM with a split tensile strength increased by $166 \%$ from control specimen. It was reportd by a study that $25 \%$ fly ash in a mixture of self-compacting concrete (SCC) increased the tensile strength of concrete by $20.51 \%$ of control specimen 
[18]. Another study on bio-concrete stated that the concrete fly ash $30 \%$ with microbes increased the tensile strength of $13.8 \%$ of fly ash concrete [19]. The filler effect of microbes revealed that it also influenced the tensile strength. This mechanism is also demonstrated by specimen OFAM where the micro-filler effect of bacteria is effective. At the optimum point ( $40 \%$ fly ash), the tensile strength with microbes increased by $10.5 \%$ when compared to ordinary fly ash concrete. The concrete with $50 \%$ of fly ash containing microbes (50FAM) shows a tensile strength reduced by $16.9 \%$ from 50FA. This is influenced by of decrease of space for microbes in the concrete-filled with fine particles fly ash. Another explanation is in the mixture with $50 \%$ FA, cement content as the main binder in concrete was reduced.

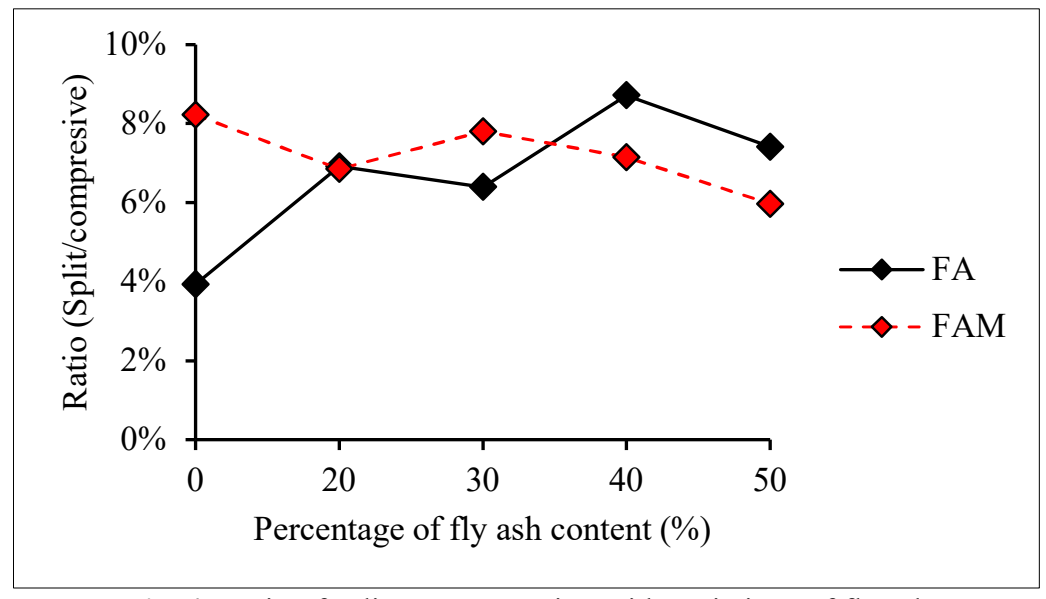

Fig. 4. Ratio of split to compression with variations of fly ash

In Fig. 4., the ratio between the split tensile strength and the compressive strength is presented. In specimen 40FA, a ratio of $8.7 \%$ is the maximum and the ratio decreases as the ash increased. It reveals that the effect of fly ash is more profound to the splitting tensile than the effect of bacterial precipitation. The effect of calcite sedimentation in concrete pores is generated first by bio-activation then followed intensively by the pozzolanic reaction.

\subsection{Concrete Workability}

The required slump in this study was in the range of $60-180 \mathrm{~mm}$. Fig. 5. provides the slump results. As the density of fly ash is less than Portland cement, more cement substitution affected the volume of ash in the mixtures increased. In general, this is the reason that the addition of fly ash causes slump tends to decrease. The slump of mixtures with fly ash content in the range of $20 \%-40 \%$ decreases because very fine fly ash particles cause some of the water that was supposed to react with cement was also absorbed by fly ash during mixing. Some reports indicated that fly ash absorbed more water than cement because the fly ash particles has irregular and porous properties [20]. However, fly ash can increase workability in concrete with a fly ash content of $0 \%-40 \%$ where it is different from addition of silica fume by $5 \%-15 \%$ reduced slump in concrete $[2,21]$. In some cases, fly ash is utilized as a superplasticizer admixture to increase the workability of concrete. The addition of microbes did not affect the value of slump in concrete. The increased slump was not caused by microbes but rather the effect was given by superplasticizer into the concrete.

In Fig. 5., the addition of fly ash requires more superplasticizer (HRWR). It was also reported that the use of fly ash varied at $25 \%, 35 \%, 45 \%, 55 \%$, and $65 \%$ required a superplasticizer of $0.05 \%, 0.1 \%, 0.15 \%$, respectively [22]. This is because of increased demand for cement as the $\mathrm{w} / \mathrm{b}$ ratio was reduced. Surprisingly, the addition of microbes affected to the mixture more 
workable. At $50 \%$ fly ash there is a significant increase in a slump because the concrete mix tends to become SCC (self-compacting concrete) due to excessive use of superplasticizer $(0.41 \%$ of binder). This is consistent with the use of superplasticizer for making SCC concrete was equal to $0.3 \%$ of the binder caused. The superplasticizer inside the concrete created a temporary dividing layer between water and cement resulting in a hydration reaction cement occurred indirectly which makes the concrete mixture if it looks more flowable [23]. The effect of gas produced by microbes was found in specimens 0FAM and 20FAM. The gas created more spaces in the fresh mixtures and enhanced the slump [24, 25].

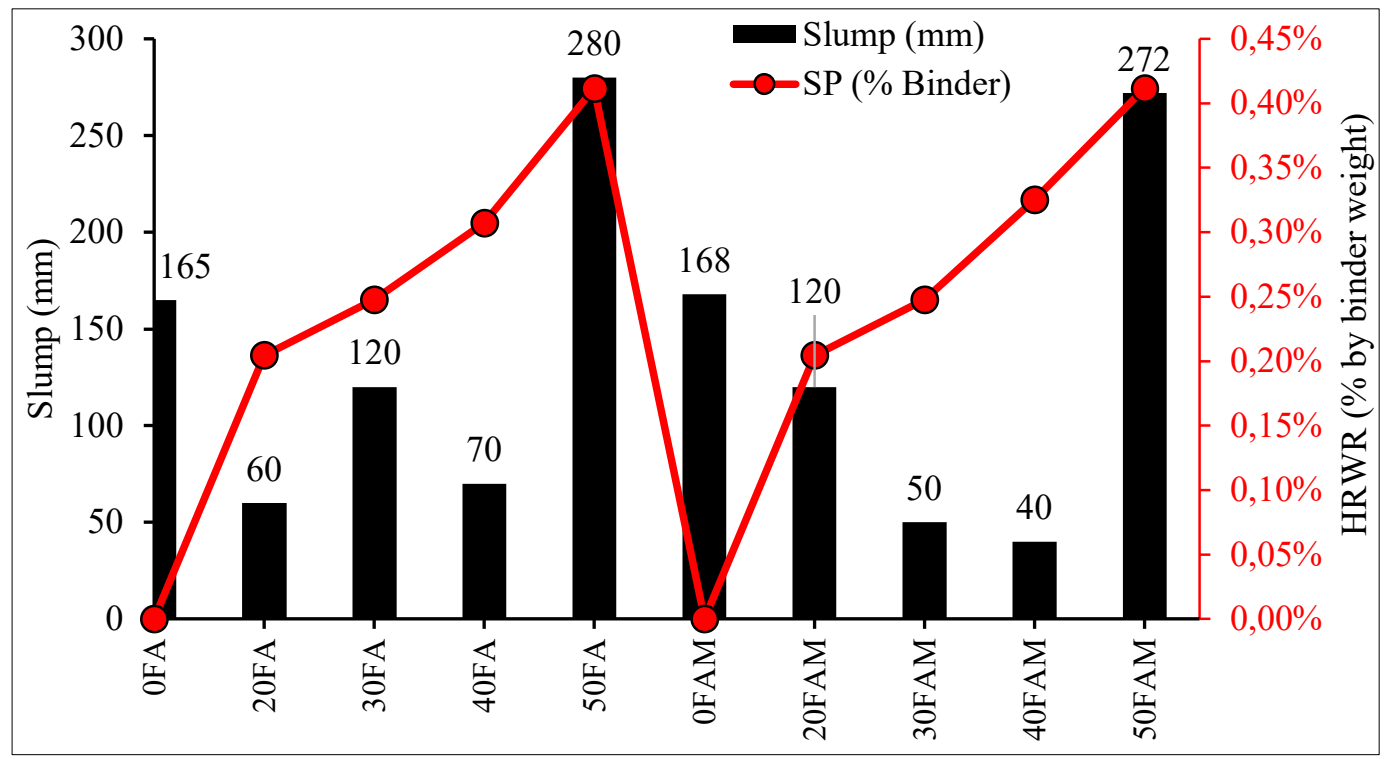

Fig. 5. The relation of the slump with the amount of superplasticizer in concrete

\subsection{Concrete temperature measurement}

The relationship of hydration temperature in 24 hours after casting is presented in Fig. 6 . with the amount of cement is provided in each mark.

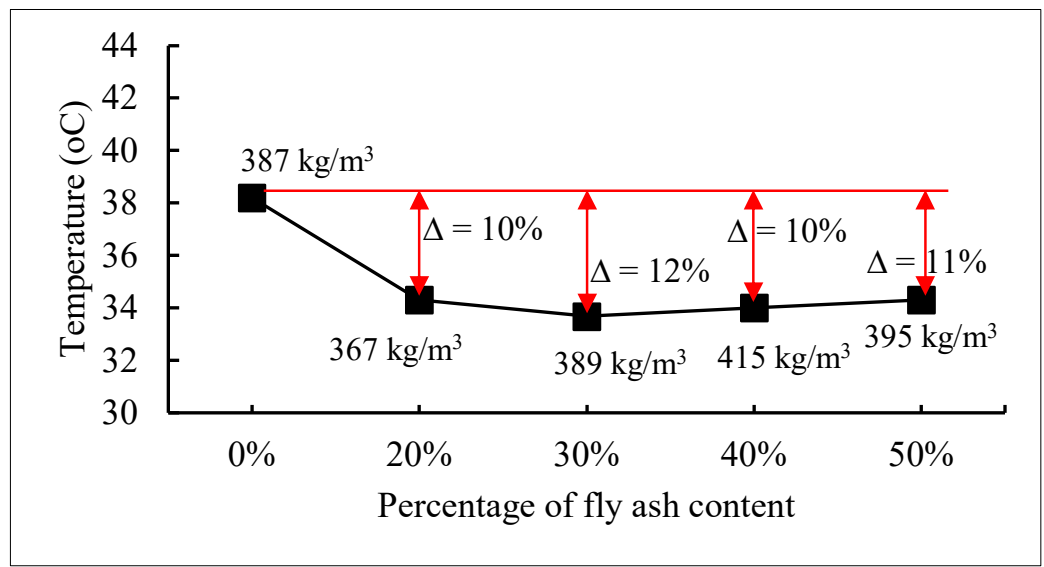

Fig. 6. The effect of fly ash content on hydration heat

The experiment is proposed by our previous study. The temperature of fresh concrete in cubical mold with a size of $15 \mathrm{~cm}$ was monitored using a thermocouple [26]. In this study, the $24 \mathrm{~h}$ 
measurement using a data logger connected to a thermocouple cable that was inserted into the midpoint of the concrete. In Fig. 6., the use of fly ash in concrete reduces temperatures to $10 \%$ $12 \%$ and the temperature started to decreaseefefctively by using $20 \%$ fly ash. and the peak decreased at $30 \%$ fly ash, after that the concrete temperature was almost same/constant. It was also reported that fly ash reduced temperature in fresh concrete from $45.2{ }^{\circ} \mathrm{C}$ to $34.5{ }^{\circ} \mathrm{C}$ with the application of $45 \%$ fly ash [27].

\section{Conclusions}

Based on the results of this study, the following conclusions can be drawn:

1. Fly ash and microbes have the same role to increase the compressive strength of concrete by filling pores concrete pores resulting in denser concrete. Concrete compressive strength at 28 days increased by $51 \%$ achieved by specimen $30 \mathrm{FA}$. In addition, the use of microbes in specimen 30FAM increased the 28 -day compressive strength by $62 \%$ from the control and increased by $11 \%$ from $30 \mathrm{FA}$.

2. In the $50 \%$ variation of fly ash, the influence of microbes was reduced, due to the limited amount of cement so that the availability of $\mathrm{Ca}(\mathrm{OH})_{2}$ or portlandite which should react with fly ash and microbes also decreases.

3. The maximum split tensile strength was $40 \%$ fly ash concrete with the increase of $166 \%$ higher than the control. The addition of microbes also affects the split tensile strength, this is shown by the bacterial specimens.. At the maximum point (40FAM) the strength of concrete with microbes increased by $10.5 \%$ when compared to $40 \mathrm{FA}$.

4. The use of fly ash by $30 \%-40 \%$ can reduce the workability of the concrete due to fine particles of fly ash. This causes water was absorbed first by fly ash before reacting with cement. More superplasticizer was required with the increase of fly ash content because $w / b$ was reduced. However, the application of microbes influence concrete workability at a lower fly ash content.

5. The effect of fly ash reduce the temperature of fresh concrete by $10 \%-12 \%$ because of reduction of cement content that lower the source of the heat.

\section{Acknowledgments}

The authors acknowledge the support received from PT Petrokimia Gresik for providing the fly ash. We also thank to PT Indocement Tunggal Prakarsa for providing the Portland Cement Composite.

\section{References}

[1] Indonesian National Standard, SNI-03-2834-2000: Procedure of Normal Concrete Mix Design, Jakarta (in Indonesian).

[2] Bahedh, M, A., dan Jaafar M, S., (2018), Ultra High-Performance Concrete Utilizing Fly Ash as Cement Replacement under Autoclaving Technique. CSCM, 202.

[3] Rafeet, A., Vinai, R., Soutsos, M., Sha, W. (2017), Guidelines for Mix Proportioning of Fly Ash/GGBS Based Alkali Activated Concretes. Construction and Building Materials, 147, 130-142.

[4] Marthinus, A, P., Sumajouw, M, D, J., Windah. R. S. (2015), Effect of Addition of Fly Ash to Tensile Strength of Concrete. Journal of Sipil Statik, 3, 11 (in Indonesian).

[5] Wang, W., Lu, C., Li, Y., Li, Q. (2017), An Investigation on Thermal Conductivity of Fly Ash Concrete After Elevated Temperature Exposure. Construction and Building Materials, $148,148-154$. 
[6] Andalib, R., Majid, M, Z, A., Hussin, M, W., Ponraj, M., Keyvanfar, A., Mirza, J., Lee, H, S. (2016), Optimum Concentration of Bacillus Megaterium for Strengthening Structural Concrete. Construction and Building Materials, 118, 180-183.

[7] Jagannathan, P., Narayanan, K, S, S., Arunachalam, K, D., Annamalai, S, K. (2018), Studies on The Mechanical Properties of Bacterial Concrete with Two Bacterial Species. Materials Today: Proceedings, 5, 8875-8879.

[8] Xu, X., Liu, X., Li, Y., Ran, Y., Liu, Y., Zhang, Q., Li, Z., He, Y., Xu, J., Di. H. (2017), High Temperatures Inhibited the Growth of Soil Bacteria and Archaea But Not That of Fungi and Altered Nitrous Oxide Production Mechanisms from Different Nitrogen Sources in An Acidic Soil. Soil Biology \& Biochemistry, 107, 168-179.

[9] American Society for Testing and Materials C 494/C 494M - 19. (2019), Standard Specification for Chemical Admixtures for Concrete. ASTM International. United States.

[10] Nursandah, A. dan Jannah, R, J. (2017), The Influence of Bioconc Expired on the Concrete Compressive Strength. Agregat, 2, 1 (in Indonesian).

[11] Wulandari, K, D., Ekaputri, J, J., Triwulan, Fujiyama, C., Setiamarga, D, H, E. (2018), Effects of Microbial Agents to The Properties of Fly Ash-Based Paste. MATEC Web of Conferences, 195.

[12] Velandia, D, F., Lynsdale, C, J., Provis, J, L., Ramirez, F. (2018), Effect of Mix Design Inputs, Curing and Compressive Strength on the Durability of $\mathrm{Na}_{2} \mathrm{SO}_{4}$-Activated High Volume Fly Ash Concrete. Cement and Concrete Composites, 3036.

[13] Gopalakrishnan, R., Sounthararajan, V, M., Mohan, A., Tholkapiyan, M. (2019), The Strength and Durability of Fly Ash and Quarry Dust Light Weight Foam Concrete. Materials Today: Proceedings.

[14] Chahal, N., Siddique, R., Rajor, A. (2012), Influence of Bacteria on the Compressive Strength, Water Absorption and Rapid Chloride Permeability of Fly Ash Concrete. Construction and Building Materials, 28, 351-356.

[15] Asgharzadeh, M., Kafil, H. S., Fahmi, A., Yousefi, M., Aghazadeh, M., Hanifi, G. R., Pourostadi, M. (2016), Optimizing The Use of Sporsarcina Pasteurii Bacteria for The Stiffening of Sand. Asian Jr. of Microbial. Biotech. Enc. Sc, 18, 2.

[16] Krishnapriyaa, S., Ventakesh, D, L., Babub, Arulraj G, P. (2015), Isolation and Identification of Bacteria to Improve the Strength of Concrete. Microbiological Research, $174,48-55$.

[17] Kim, T., Davis, J, M., Ley, M, T., Kang, S., Amrollahi, P. (2018), Fly ash Particle Characterization for Predicting Concrete Compressive Strength. Construction and Building Materials, 165, 560-571.

[18] Kavyateja, B, V., Jawahar, J, G., Sashidar, C. (2020), Effectiveness of Alccofine and Fly Ash on Mechanical Properties of Ternary Blended Self Compacting Concrete. Material Today: Proceedings.

[19] Kadapure, S, A., Kulkarni, G, S., Prakash, K, B. (2016), A Laboratory Investigation on The Production of Sustainable Bacteria-Blended Fly Ash Concrete. Arab Journal Science Engineering.

[20] Nguyen, T, B, T., Saengsoy, W., Tangtermsirikul, S. (2018), Effect of Initial Moisture of Wet Fly Ash on the Workability and Compressive Strength of Mortar and Concrete. Construction and Building Materials, 183, 408-416.

[21] Siddique, R., Jameel, A., Singh, M., Barnat-Hunek, D., Kunal, Ait-Mokhtar, A., Belarbi, R., Rajor, A. (2017), Effect of Bacteria on Strength, Permeation Characteristics and MicroStructure of Silica Fume Concrete. Construction and Building Materials, 142, 92-100.

[22] Nagrockienè, D., Rutkauskas, A. (2018), The Effect of Fly Ash Additive on the Resistance of Concrete to Alkali Silica Reaction. Construction and Building Materials, 201, 599-609.

[23] Benaicha, M., Alaoui, A, H., Jalbaud, O., Burtschell, Y. (2019), Dosage Effect of Superplasticizer on Self-Compacting Concrete: Correlation between Rheology and Strength. Journal of Materials Research and Technology, 8, 2063-2069. 
[24] Shahrin, R., Bobko, C, P. (2019), Micropillar Compression Investigation of Size Effect on Microscale Strength and Failure Mechanism of Calcium-Silicate-Hydrates (C-S-H) in Cement Paste. Cement and Concrete Research, 125, 105863.

[25] Nain, N., Surabhi, R., V, Y, N., Krishnamurhty, V., Deepa, T., Tahrannum, S. (2019), Enhancement in Strength Parameters of Concrete by Application of Bacillus Bacteria. Construction and Building Materials, 202, 904-908.

[26] Ekaputri, J, J., Ishida, T., Maekawa, K. (2010), Autogeneous Shrinkage of Mortars Mode with Different Types of Slag Cement. JCI Annual Conferences, Saitama, 7-9 July 2010, 1.

[27] Matos, P, R, D., Junckes, R., Graeff, E., Prudêncio, L, R., Jr. (2020), Effectiveness of Fly Ash in Reducing the Hydration Heat Release of Mass Concrete. Journal of Building Engineering, 20, 101063. 